Global Norms in the Twenty-First Century

Edited by

Klaus-Gerd Giesen and Kees van der Pijl

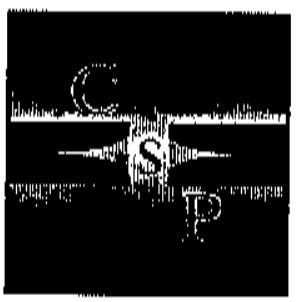

CAMBRIDGe SCHOLARs PRESS 
CHAPTER 8

\section{INTERNATIONAL STANDARDISATION AND CORPORATE DEMOCRACY}

\section{JEAN-CHRISTOPHE GRAZ}

\section{Introduction}

This chapter ${ }^{1}$ explores the role of international standards in governing the world economy. There is a growing literature on how norms of behaviour explain rules of collective action. Here, however, my entry point in the debate will be standards as technical specifications used in production, consumption, and exchange. Wedged in between domestic voluntary measures and global rules, standards affect virtually every aspect of our daily life. Thousands of standards define the interoperability of computers, credit cards or mobilc phones, but also the resistance of plate glass. Few people arc familiar, however, with the struggles between consortia of multinational enterprises and state regulators for defining standards that allow economies of scale and market access across borders, or not. Current initiatives to develop international standards for funeral services, personal financial planning, healthcare and education, only highlight the manifold implications.

The proliferation of standards is not so much an issue of (inter-) governmental versus non-state norm-setting practices; these have been found to be largely complementary and much less an area of conflict. ${ }^{2}$ International standardisation rather points towards an emerging model of "corporate democracy". According to Heiskanen, corporate democracy departs from the Enlightenment ideal of popular sovereignty or universal citizenship, and represents a rupture with classical liberalism. Instcad, "the participation of individuals in transnational governance is not viewed as a matter of universal, formal right, but as a consequence of an individual's holding of certain contextspecific professional interests or concerns".3 Standard-setting bodies are highly influential in this domain but provide only biased participation capabilities in this respect. They operate in the interstices between contractual relations and the mandatory rule of the law, remaining largely outside the purview of democratic institutions and therefore, liable to questions conceming their legitimacy.
Current developments in this area are riddled with conflict. On the one hand, large multinational corporations aggressively lobby to limit the scope of standardisation to specifications conducive to economies of scale; on the other hand, most official standards bodies are rather inclined to expanding the public authority of standards by widening their scope. Rather than a public/private, or state/market divide, we are looking at a rift confronting the advocates of further socialisation of international standards (that is, bringing standard-setting bodies into a universal legal domain), and advocates of a commodification of technical standards (minimal sector and market-bascd standards, universally recognised).

Four dimensions can be distinguished here. The first two map out the comprehensive topology of standard-setting organisations: one, on a continuum that runs from a market of private technology to public law; the other, on a continuum from natural and invariable physical measures (e.g., weights and mcasures), to construcled and historically specific societal values (e.g., health and safety measures). The two other dimensions concern the differentiated processes of standardisation once definition and content have been agreed, and organisational procedures and territorial competences involved in implementation, are at issue.

\section{The Changing Context of Standardisation}

Standards refer to voluntary technical specifications explicitly documented and published for use in the organisation of production and exchange and, more broadly, for regulating the domestic and the international economy. Standards codify technical specifications regarding measurement, design, performances, or side effects of products, industrial processes, or services. It is more than two decades now since major developments began to take place in this domain. Previously, technical specifications were mainly confined to state regulations, corporate standards emanating from management decisions, or domestic standard-setting bodies. Today, technical specification has become, to a large extent, the outcome of voluntary standards developed in a set of public and private bodies at the global or regional level.

At the regional level, the European Union is in the forefront of international standardisation. ${ }^{4}$ In 1985, Council Resolution 85/C 136/01 on a "New Approach" to technical harmonisation and standardisation has instigated a completely new regulatory technique and strategy. The resolution was a rcsponse to the growing role of the European Court of Justice in solving conflicting regulatory policies in the internal European market. It was also an early move towards the completion of the Single Market by devising procedures to avoid turning technical specifications into a structural impediment to trade. Although member states werc wary about seeing regulation in this domain 
transferred to the European authorities, they did perceive the threat of a race to the bottom in public purposc standards as integration progressed. The New Approach provides a framework for the harmonisation of EU public law only on the general and essential requirements of goods and services traded on the European market, in particular in the field of health, environment, safety, and consumer protection. Depending on the sectors affected, technical specifications, performance critcria and quality requirements are either based on mutual recognition of national standards, or delegated to Europcan standardsetting bodies such as CEN (Comité europén de normalisation), Cenelec (Comité europeen de normalisation électrotechnique), and Etsi (European Telecommunications Standards Institute). In most sectors, the procedure for monitoring standards is a matter of business self-regulation, since products put on the market are granted a presumption of conformity through the sole declaration of the manufacturer (CE marking). Thus, the European New Approach has not only strengthened the importance of voluntary standards in the Single Market. By avoiding costly third party testing and certification, and providing the procedural means for a simultaneous adoption of European standards as international ones (through the so-called Dresden and Vienna Agrecments), the EU has also won over third countries to its standardisation systcm. The (largely unintended) outcome has been a powerful strategic positioning of European standards in the global market. ${ }^{5}$

In contrast, standardisation in the United States hinges upon hundreds of privatc sectoral bodies, with public agencies involved when societal concerns or defence contracts are at issuc. The recognition of standards is still largely made through the costly procedures of third party certification; manufacturers" declarations of conformity are only used in specific sectors. ${ }^{6}$ For decades, the prominent position of the United States in technological innovation granted de facto international acceptance for numerous standards developed and tested by these bodies. But for more than a decade, a widening rift has emerged between the Unitcd States and Europe on international standardisation. The controversy has erupted in a context of competing industrial policies, opposed legal systems, and disagreements on the respective role of private actors and public authority in standards development and implementation.

No single international organisation encompasses all aspects of standardsetting. The Interational Organization for Standardization (ISO), the International Electrotechnical Commission (IEC), and the International Telecommunication Union, Section Standardization (ITU-T), are the three organisations that embody the universal potential of international standardisation most emphatically. ${ }^{7}$ ITU-T is a specialised agency of the United Nations system. Unlike other UN bodies, however, its membership not only includes statcs, but also privatc operators, manufacturers, regulatory bodies and other intergovernmental and non-governmental organisations in the field of telecommunication. ISO and IEC on the other hand have a membership of around 140 non-governmental national bodies "most representative of standardisation in their country". Only one body in each country is eligible to membership. Thus there is a mixture of private and public bodies when it comes to official international standard organisations. Mixed private-public bodies have lately claimed a greater degree of autonomy through performance-oriented contractual relations with government ministries and by creating subsidiaries spccialising in the most profitable activities. Recent statutory changes of the British Standards Institute (BSI), or the Association française de normalisation (Afnor) illustrate this trend.

At the international level, the World Tradc Organization (WTO) has given fresh impetus to the standardisation process. The entry into force of the WTO Technical Barriers to Trade (IBT) Agreement and the rcvision of the Sanitary and Phytosanitary Measures (SPS) Agreement in 1995 marked the formal devolution of power to international standards-setting organisations. Unlike the loose provisions regarding technical regulation of the old GATT, the TBT and SPS Agreements (and the same applies to certain provisions of the General Agrecment on Trade and Services, GATS) give international standards a major role in harmonising the technical specifications of goods and services traded in the global market. In the manner of the European New Approach, statc regulation in this domain must comply with "lcgitimate objectives", such as health, safety and environmental conccrns. The goal of removing "unnecessary" barriers to trade is to be pursued, where possible, by substituting domestic standards by international ones. ${ }^{8}$

To sum up, the Europern New Approach and the improved disciplinc of the WTO have worked to shift a large set of technical specifications hitherto in the domain of production, or covered by domestic public regulatory policics, to voluntary international standards. But who is in charge of defining internationa standards - and in which areas? Who assesses conformity to an agreed standard? In fact, as a recent World Bank study concludes, a host of private and public bodies decide "what can (or cannot) be exchanged, and outlinc the procedurcs under which such exchanges are or are not permissible". 9 The reason why standards epitomize an emerging model of corporate democracy, I would argue, is because they represent a hybrid form of power and authority in the global political economy, removed from established democratic institutions.

\section{Conceptualising Standards}

Today there exists a well-developed literature on standardisation, written by academics and practitioners alike. Even so this literature remains "onc-sided, as 
it mostly concentrates on standards battles and examples are mainly taken from information and communication technology". 10 From a political economy perspective, the question of standards is closely linked to the relationship between the drive for technical specifications and the institutional framcwork requircd to ensure some order in this area at the transnational level. As Mattli points out, "the literature on standards setting generally lacks a sustained theoretical argument to explain or assess institutional standards arrangements past or present"."1

Some neo-institutional approaches have tried to explain the nature of the relations between private actors involved in standardisation and the institutional environment in which their actions take place. Borrowing the concept of transaction costs from institutional economics, these studies consider how the practices of agents can be defined by their environments to a considerable extent. From this perspcctive, standardisation provides an institutional guarantee for improving trust in transactions and curbing free riding risks. Mattli and his co-authors are representative of a majority of studics relying on rational choice and game theories to formalise systematic explanations of cooperative games and conflicts of distribution in the institutional framework of standardisation. In this vicw, the logic of action trumps its content and the understanding of the power relations involved in standardisation is confined to quantifiable and $a$ priori defined criteria. ${ }^{22}$

Other studies adopt a more critical perspective on the socially and historically constructed institutional framcworks of standardisation and their diversity across the globe. They provide an account of beliefs underpinning standards, democratic controls of so-called independent regulatory authorities, or conflicts of power in specific negotiations. ${ }^{13}$ Such analyses shed light, for instance, on the debate between the strongly institutionalised ISO and Europcan systems, the more competitive pattern in the United States, and the oligopolistic nature of consortia agreements, ${ }^{14}$ Yet, they fail to recognise the structural nature of power relationships in the organisation of a capitalist world economy. The concept of structural power refers to material and discursive structures able to affect (intentionally and unintentionally) the practices of agents; hence those able to wield this power can modify the general environment for their own benefit. ${ }^{15}$ The structural power of standardisation epitomises onc among several new forms of non-state authority that have evolved over the past decade in the global political economy.

According to a recent OECD study, up to 80 percent of world trade is affected by standards or associated technical regulations. ${ }^{16}$ The scope of international standards not only pertains to their potential worldwide reach, but also to the whole range of conflicts emanating from the industrial system. ${ }^{17}$ Assessments of the rclationship between standard-setting agencics and society as a whole are therefore bound to be controversial. Workers will look to standards to ensure a safer workplace (e.g., standards on machine safety or maximum noise pollution) or obtain quality guarantees on the wage goods they purchase; industrialists on the other hand will equate standards with market access, technological progress, and strategic competitive bchaviour. Let us pursue this from a structural power perspective.

\section{A Comprehensive Topology of Standards}

The topology of international standardisation begins with the subjects involved in defining standards and the distinction between the private and public spheres in which they opcrate. Market mechanisms and policy choices both affect the agents involved in the field, but they do so in various ways, which may be seen as located on an institutional continuum. Technical specifications belong to the private sphere of economic activities governed by market constraints, and affect social and technological change from that angle. Yet, they can also be related to the public sphere of political action directed to the general interest of societyfor instance by determining a certain level of risk or by setting principles of liability. Hence, even in the circumscribed field of technical specification, norms relate as much to capital accumulation and technical progress as to social improvement or various instruments of the welfare state.

When mandatory, enforceable and general, technical specifications are a matter of public law and enjoy the status of government regulation. Many environment, health and safety measures belong to this class of measurcs, such as the environmental and sanitary policy of the European Union based on the precautionary principle. Likewise, a whole battery of regulatory requirements in health and safety are part of the labour laws of the United States and other industrialised countries. Issues of labelling food packaging have become part and parcel of market regulation policies focused on consumers" protection. In fact, all these regulations usually include voluntary standards in one way or another, as countries include or refer to them in their national regulatory framcwork. In such cases, tcchnical spccifications bring in standard-setting organisations into the regulatory arena. As we have seen, the institutional mix of public and private bodies involved in the official process of international standardisation varies considerably across the globe. But there is usually a privileged relationship with states.

If we move further in the direction of the private domain, we come across strictly private organisations specialised in setting and providing standards. Here, standards are dcveloped by bodies rcsembling industry and trade associations seeking to ease the burden associated with expanding the scale of their activitics. Yet, many of the standards set by private collective agreement 
set the goalposts for government regulation as well. The complex web of private standards agencies in the United States, involving hundreds of sectoral bodies, is a key cxample. A dozen of these set more than 90 per cent of standards in the oil, automotive, and electro-technical industry and areas of application. Two key playcrs stand out here: the American Society of Mechanical Engineers (ASME) and the American Society for Testing and Materials (ASTM).

Further into the private spherc, de facto or consortium standards are marketbascd to an even greater extent. These standards reflect the convergence towards an agrecd technical specification that is openly accessiblc, yet developed by a restricted number of manufacturers who are the leaders in technological change in their industry. Until recently, they dealt primarily with the compatibility of components required for the development of new products (like CD-Rom or DVD), or with the modes of intcropcrability in the field of telecommunication and information technology (e.g. the TCP-IP protocol used for connecting computers into a single worldwide network). Of late, however, a range of initiatives have been taken to promote such standards with a much broader scope. Corporate social responsibility benchmarks are a case in point. Consortium standards involve collective action of a distinctly oligopolistic naturc, which hence must be situated at the private end of the institutional continuum of standardisation, notwithstanding the tight imbrication with govcrument industrial policy on certain strategic issues, ${ }^{18}$

When consortium standards relate to technical choices only, they generally include technological scquences protected by legal intellectual property rights (IPR). However, companies owning patents in this connection do not necessarily make full use of their rights. They may also prefer to ensure the widest diffusion of a key technology within the industry in which they are prime movers. This explains oligopolistic arrangements like the strategic alliances adopting the GSM standard in mobile telephony, or through monopolistic behaviour, as in the casc of the algorithms of the Windows operating system owned by Microsoft and applied on most computers around the world. Such an ability to control or subvert the standardisation process and guide technological innovation in an entire sector with a combination of patents, licensing agreements, and IPR protection, engenders profound company rivalrics. It epitomizes the extremes of the privatisation of standardisation. ${ }^{19}$

The recent developments of private standards consortia, their de facto power, and their extending scope, have clearly impacted upon the official institutional framework of international standards. For companies, consortium standards enable a gteat procedural flexibility and a shorter time-span needed to reach agreement (often less than a year). This is a considerable advantage, given that economies of scale are required to ensurc quick returns on the hugc investments in prior rescarch and development and product cycles are in the range of 12 to
18 months in new technologies. Accordingly, official institutions such as iSO and CEN have developed new procedures and so-called "new deliverables" for technical specification, which are obligatory and must be published swiftly. This may reduce the degree of consensus nccessary for an agreement, whilst the process also is speeded up by clectronic voting. Consortia as a result have become more inclusive with morc participants involved, including public and NGO participants-a sign of the enhanced respectability of de facto standards. Clearly this process of regulation by technical standards for goods and services exchanged across borders, is not so much a matter of a conflict between public laws and standards. It involves the cntire institutional continum along which public and privatc agents compete for defining how, and to which extent, markets should be integrated.

Objects covered by technical specifications also structure the comprehensive topology of standardisation. Whereas the private/public nexus of the subjects involved in defining standards can be located on an institutional continum this second dimension should be situated on a material continuum delineating whot can be standardised. This goes back to the relation between human beings and nature. What we call technical specifications, range from natural and invarable physical measures (with undisputable properties), to constucted and historically bounded societal values, which are always contestable. Here we encounter a range of issues which have been relegated to the margins of the political agenda for perhaps too long.

The stages by which standardisation has moved from one pole of this material continum to the other, arc to somc extent historical. The French Revolution invented, ex nihilo, the decimal metric system. The increasingly large scale of capitalist industries and rapid technological innovations of the Second Industrial Revolution then led to material product standards defining performance and interoperability, notably in spare parts, iron and steel properties and dimensions for structural material used in railways or shipping, electrical systems and communication. Health and safety concerns linked to the welfare state prompted the devclopment of standards in domains more directly related to consumers rather than producers. More reccntly, outsourcing in the devclopment of global value chains and increasing concerns about environmental regulations potentially used as non-tariff trade bartiers, have contributed to a shift towards quality and environmental management standards in the 1980s and 1990s, and so on to the still largely untouched territory of standards in the service sector.

The image of a continuum on this dimension is to some extent contradicted by the fact that the extremes (nature/history) occasionally overlap. For instance the invention of the decimal metric system by the French revolutionaries vindicated the Enlightenment belief in the power of Reason and abstraction in 
the domain of measurement by defining the metre as one millionth of a quarter of the Earth's meridian. Yet it was also a way to abolish the arbitrary system of "two weights, two measures" used by lords to manipulate the peasants" grain levy. More generally, following the political homogenisation of human beings under the Declaration of Rights of Man and Citizen in 1789, French revolutionaries took the planet Earth as the basic standard of all measures: length, surface, volume, mass, taxes, coinage, ctc. As Denis Guedj puts it in his history of the invention of the decimal metric system, in their pursuit of a truly universal, invariable and natural standard, Talleyrand, Condorcet and others searched for a concept that was both social and "hard", and which by its inherent natural quality would prove binding to all of humanity. ${ }^{20}$

So if regulatory policies are closely related to technological change and innovation issues, they also reflect broader social concems. Against the widely accepted instrumental vicw of technology as a neutral tool, a critical appreciation of the objects falling within the scope of international standardisation reveals to what extent technology remains an ambivalent process embedded in constellations of power entailing different possibilities. Feenberg characterises technology as a "parliament of things in which civilizational alternatives are debated and decided". ${ }^{21}$ In brief, the object of standardisation incvitably blends the physical and social requirements of a material civilization.

\section{Differentiated Processes of Standardisation}

Beyond the stage of agreement reached on definition and content, standardisation can be differentiated depending on the various ways standards are implemented. We need to distinguish here between standardization per se and recognition of standards. While international standardisation is driven by the attempt to homogenise specifications across national jurisdictions, processes of standards recognition allow for the acceptance of a plurality of standards or means of assessing conformity with them. In other words, this second analytical grid does not focus on the content of an assumed greater uniformity of standards worldwide, or of the competing bodics involved in this agenda. Its main concern is with the conditions under which a plurality of standards can operate without contradiction and the conformity of their implementation be mutually recogniscd, Even if the process of unifying standards is continuing, disparities in the method of assessing how firms comply with them can still be a persistent source of trade tensions. A set procedure for testing physical resistance of a product does not mean, for instance, that any laboratory able to do the test will be recogniscd as a certified tester. Regulation can drastically limit conditions for such recognition. Or, if the process of standardisation runs into difficulty in the attempt to achicve global harmonisation, those seeking integration of world markets may resort to mutual recognition as an alternative. In Europe, for instance, products not subject to technical harmonisation at the EU level should in principle be exchangeable freely and just conform to domestic specification and regulations of a member state. The differentiated processes of standard recognition worldwide thus can be understood on two dimensions: the organisational procedures involved in standards recognition on the one hand, and the territorial compctence on which the assessment of conformity is predicated, on the other.

The first dimension concerns the organisational procedures for recognising conformity to an agreed standard. To comply to a set of technical specifications, market agents follow different proccdures, framed in various ways by the institutional bodies in charge of conformity assessment policy. Such procedures can again be located on a continuum with the public and private spheres at each extreme, as in the case of the institutions defining standards. A public system of standards recognition hinges upon established authorities, whercas a private one mostly involves contractual relations and market mechanisms. Of course there are issues of trust and power involved in the choice between public organisational procedures and privately organised market relations. Our willingness to move from onc end of the continum to the other depends how much we trust agents and institutions involved in conformity assessment.

Theoretically, while standards per se already signify a transfer of trust from price signals to technical specification, standards recognition implies a further shift in the level of trust. The concept of trust has become widely used in economic sociology to account for the embeddedness of market relations into wider organisational, social and political arrangements. Some authors even consider that the issue of trust may eventually challenge the traditional organisation of capitalism because the centrality of market pressures as the reference for political power is not neccssarily an acceptable condition for society at large. 22 More broadly, the issue of trust reminds us of Durkheim's argument that the social contract must involve something elsc than itself otherwisc contractual solidarity would suffer by the reliance on upholding the social contract by the threat or the use of force. ${ }^{23}$

In practice, the trust continuum runs across a wide range of organisational procedures. At the extreme of private relations, we find declarations of conformity directly supplied by the manufacturer and generally accepted as such (as most products conforming to the CE mark found on packaging). At the opposite public extreme, we may still find numerous organisations that provide "third party" certification, testing or inspection serviccs, whose competence and integrity is itself assessed by a public accreditation body (accreditation understood as the procedure by which an authority extends formal recognition that a body or person is competent to carry out specific certifying tasks). ${ }^{24}$ As 
Tronel notes, "for a given requircment of conformity, there arc an increasing number of possible distinct responses". 25 Organisational procedures run from suppliers' autocertification to verifications with tests and controls for each product placed on the market by a public certification body, itself publicly accredited. In between, onc can find all sorts of arrangements such as quality insurance systems relying on ISO 9000 standards serics certified by publicly accredited private companies (like Inspectorate or SGS), or declaration of conformity based on private "peer assessment schcmes" between companies active in the same industry.

The second dimension on which differentiated processes of standards recognition are executed worldwide is territorial competence. In order to understand this issue, we necd to distinguish between wogenous and endogenous principles of standards recognition. These opposing mechanisms of recognition have implications in terms of a transfer of authority and lcgitimacy in contemporary democratic states, As Nicolaïdis and Egan observe, "domestic regulators accept unprecedented transfers of regulatory sovereignty by recognizing non-domestic standards as valid under their jurisdiction, whether they have taken part in their development (standardization) or not (recognition)" 26 Indeed, rccognition of standards may or may not involve domestic regulatory bodies. It depends on the domestic acceptance of certificates issued in foreign countrics. Theoretically, if fully accepted on a worldwide basis, the various ways of assessing conformity to a given standard would ensure market acccss on a purely exogenous basis. In practice, a supplier would only need one certificate to satisfy the entire market and al governments - as in the motto of the advocates of the system, "one market, one standard, onc test, globally accepted". On the other hand, if none of the various ways of assessing conformity to a given standard were rccognised on an international basis, the technical specification for market access would come to rely on a strictly endogenous basis. Concretcly, this would involve multiple replications of tests and certifications before gaining clearance for entering each domestic market.

Various instruments have been negotiated to define the territorial competence of conformity assessment procedurcs. In order to increase the confidence of both private and public agents in the market, cross-border cooperation has been developed on a bilateral or plurilateral basis among conformity assessment and accreditation bodies. Under so-called Mutual Recognition Agreements (MRAs), governments agree to rccognize the results of each other's testing, inspection, certification or accreditation bodies in specified industries. Platforms such as the Transatlantic Business Dialogue aggressively lobbied for such arrangements in the $1990 \mathrm{~s}$, but the difficulties involved in finalising the agreements and the role that continues to be given to third party certification, have meant that MRAs did not in the end bccome the avenue to world market integration that had been expected. ${ }^{27}$

Recent developments appear to point in two directions. On the one hand, there are calls for a greater scope for self-declaration of conformity, in which companies would avoid the costs of third-party assessment by taking their market reputation as a liccnce to dispense with independent assessment of conformity. On the other hand, there is an attempt to focus on a superior level of territorial competence, the one involving accreditation bodies. As Pierre explains, "This is the last level of control (there is no accreditation for accreditors). Therefore, accreditory bodies should not be competing, neither between themsclves, nor with [certification] bodies which are or arc expected to be accreditatcd [by them]". ${ }^{28}$ Indeed after more than a decade of mutual ignorance, the two private bodies in charge of promoting an international acceptance of accreditation of laboratories and certifiers in 2004 established a high-level working group with the ISO ${ }^{29}$ Its purpose is to act as a clcaringhousc for dealing with issues surrounding conformity assessment policy and extend the scope of mutual recognition across borders. Included in their agenda is the expccted status to be given to numerous multilateral agreements negotiated betwcen private parties involved in certification and testing. The world's first truly international system for acceptance of test reports dcals with the safety of electrical and electronic products, as developed in the IECEE CB Schcme of the International Electrotechnical Commission (IEC).

For standardisation officials and experts, the teritorial competence for recognising conformity assessment procedures, boils down to the extent to which "global relevance" for implementing standards can be reconciled with social acceptance..$^{30}$ According to Helmut Reihlen, former Executive Officer of the Deutsches Institut für Normierung (DIN), "the bottom line remains the relationship between the process of scientific discovery and democratic control on the use of science".31 Ultimately, the debate concerns the autonomy of a society not only to define a standard, but also to control compliance with any given standard. This presumes a capacity to assess science, technology, and democracy in ways that do not lock out others and to provide, as Feenberg puts it, "a coherent civilizational alternative based on a system of mutually supporting transformations of social institutions, culture, and technology".,32 Accordingly, each time we recognise an exogenous territorial competence to standards recognition processes we end up giving up an additional fragment of autonomy. 